\title{
Efficiency of eugenol as anesthetic for the early life stages of Nile tilapia (Oreochromis niloticus)
}

\author{
PAULA A.P. RIBEIRO, KLEBER C. MIRANDA-FILHO, \\ DANIELA C. DE MELO and RONALD K. LUZ
}

\author{
Escola de Veterinária, Departamento de Zootecnia, Laboratório de Aquacultura, \\ Universidade Federal de Minas Gerais, Av. Antônio Carlos, 6627, 31270-901 Belo Horizonte, MG, Brasil
}

Manuscript received on February 24, 2014; accepted for publication on August 6, 2014

\begin{abstract}
In aquaculture, activities with anesthetic compounds are usually used in order to ensure the welfare of farmed fish, allowing handling out of water with decreased trauma by stress. Presently, there is no information about anesthetic action of eugenol in early life stages of Nile tilapia (Oreochromis niloticus). The objective of this study was to evaluate different concentrations of eugenol for larvae and juveniles of Nile tilapia. Sixty animals were used for each group of weight, group $\mathrm{I}=0.02 \mathrm{~g}$; group II $=0.08 \mathrm{~g}$; group $\mathrm{III}=0.22 \mathrm{~g}$; group IV $=2.62 \mathrm{~g}$; and group $\mathrm{V}=11.64 \mathrm{~g}$. The eugenol concentrations tested were $50,75,100$, 125,150 and $175 \mathrm{mg} \mathrm{L}^{-1}$. No mortality was reported during the tests with eugenol. Tilapia larvae with $0.02 \mathrm{~g}$ and juveniles around $11.64 \mathrm{~g}$ can be anesthetized with eugenol concentrations between 150 and $175 \mathrm{mg} \mathrm{L}^{-1}$, since they determine the shortest sedation time (23 and 72 seconds, for the group of lowest and highest weights, respectively).
\end{abstract}

Key words: anesthesia, cichlid, handling, welfare.

\section{INTRODUCTION}

In fish farming, handling procedures are common during routine work or research. These activities (netting, tagging, sorting, vaccination, weighing, transporting, surgical procedures, etc.) are associated with acute stress of animals. Fish often struggle during handling, which can lead to injuries, increasing susceptibility to infectious diseases. This is even more relevant when handling is required in early life stages (e.g. larvae and juveniles) because the loss of young animals is very common, in view of their weakness. According to some authors

Correspondence to: Kleber Campos Miranda-Filho

E-mail:kmiranda2010@ufmg.br/kleber08@gmail.com
(Waterstrat and Pinkham 2005, Palic et al. 2006, Zahl et al. 2011), the use of appropriate anesthetics is considered an important activity in aquaculture because it can reduce possible suffering of fish.

However, the lack of knowledge about anesthetics may be the limiting factor for the use thereof (Inoue et al. 2003, Vidal et al. 2006). The concentration and efficacy required for induction may vary among species, age, size, gender and even among the parameters of water quality (Walsh and Pease 2002, Woody et al. 2002, Gomes et al. 2011). According to the literature, proper immersion anesthesia may decrease the incidence of adverse effects and lead to a milder recovery (Acerete et al. 2004, Zahl et al. 2009). 
The choice of anesthetic is based on economic viability and legal implications (Cho and Heath 2000). Data on sedation consider that the product should have characteristics such as short periods of induction and recovery, 180 and 300 seconds respectively, easy application and low risk to animals, humans and the environment (Marking and Meyer 1985, Keene et al. 1998).

The evaluation of the degree of insensitivity is based on the observation of animal behavior (Walsh and Pease 2002, Hoskonen and Pirhonen 2004), starting with the reduction of opercular movement, until complete loss of response to manipulation (Woody et al. 2002).

Chemicals such as benzocaine, tricaine methanesulfonate (MS 222), 2-methylquinoline (quinaldine) and 2-phenoxyethanol can be used as anesthetics for fish (Hovda and Linley 2000). However, some of them are expensive and difficult to obtain, and often have a low safety range, which may lead to mortality if the recommended dosage are exceeded (Roubach et al. 2005). Other restrictions also exist for some of these products. For example, MS-222 was approved for use as an anesthetic in fish, but a period of 21 days to get rid of this compound is necessary and it is also considered a carcinogen (Anderson et al. 1997). In the case of benzocaine, Bressler and Ron (2004) described that this anesthetic is associated with the suppression of cells involved in immune system response in gilthead seabream Sparus aurata.

The eugenol (4-allyl-2-methoxyphenol) is natural and is the main constituent of clove oil, contituting about 70-95 \% and can be used as an anesthetic substance (FDA 2002, Ross and Ross 2008). It is a phenolic compound extracted from the leaves, flowers and small branches of the tree Syzygium aromaticum (Eastern Hemisphere) or Eugenia caryophyllata and Eugenia aromaticum (Western Hemisphere). It is considered relatively inexpensive, not unpleasant to handle and harmless to the user (Keene et al. 1998, Griffiths 2000).
Guénette et al. (2007) studying the pharmacokinetics of eugenol in rainbow trout Oncorhynchus mykiss, reported half-life of $12 \mathrm{~h}$. More recently, Delbon and Ranzani-Paiva (2012) described that the eugenol residue is eventually removed from the body of the fish in up to $24 \mathrm{~h}$. This substance acts as a depressant of the central nervous system causing anesthesia and reduction of breathing movements and heartbeats (Anderson et al. 1997).

The tolerance of fish to eugenol exposure varies according to the species. Keene et al. (1998) working with $O$. mykiss juveniles, estimated the Median Lethal Concentration $\left(\mathrm{LC}_{50}\right) 96 \mathrm{~h}$ as $9 \mathrm{mg} \mathrm{L}^{-1}$ of eugenol, and Charoendat et al. (2009) reported for tilapia juveniles (mean weight $3.0 \mathrm{~g}$ ), $\mathrm{LC}_{50} 24 \mathrm{~h}$ as $16.95 \mathrm{mg} \mathrm{L}^{-1}$.

Based on data described in recent studies, eugenol has been considered effective as a fish anesthetic (Honczaryk and Inoue 2009, Okamoto et al. 2009, Da Cunha et al. 2010, Delbon and RanzaniPaiva 2012, Ribeiro et al. 2013). However, studies reporting the effects of eugenol in early life stages of fish are still scarce demanding more information.

The aim of this study was to evaluate the efficiency of eugenol as an anesthetic for the early life stages of Nile tilapia under laboratory conditions.

\section{MATERIALS AND METHODS}

The assays were carried out at the Aquaculture Laboratory of the Federal University of Minas Gerais, Veterinary School, Brazil.

FISH

Tilapia larvae were maintained in $30 \mathrm{~L}$ tanks in a recirculating water system, with a temperature of $27.0 \pm 0.5{ }^{\circ} \mathrm{C}$, dissolved oxygen $>4 \mathrm{mg} \mathrm{L}^{-1}$, $10 \mathrm{~h}$ photoperiod. During the first 30 days, fish were fed five times a day (8:00, 10:00 and 12:00 a.m.; 2:00, and 4:00 p.m.) with commercial tilapia diet containing $50 \%$ crude protein $\left(\right.$ Fri-Ribe ${ }^{\circledR}$ ). Juveniles were fed four times a day (8:00 and 11:00 a.m.; 2:00 and 5:00 p.m.) with commercial tilapia diet containing $40 \%$ crude protein (Fri-Ribe ${ }^{\circledR}$ ). 


\section{ANESTHETIC}

The eugenol was diluted in $5 \mathrm{~mL}$ of absolute ethanol PA in the concentrations to be tested in $1 \mathrm{~L}$ of water, using $2 \mathrm{~L}$ polyethylene containers. The water used for fish induction and recovery was provided by a recirculation water system used to maintain the fish. The variables of water quality, temperature, dissolved oxygen and $\mathrm{pH}$, were measured in all replicates (with and without anesthetic) using a multiparameter probe (YSI 6920 VZ2).

\section{EXPERIMENTAL PROCEDURE}

Sixty animals were used in each group of weight: group I $=0.02 \pm 0.001 \mathrm{~g}$; group II $=0.08 \pm 0.007 \mathrm{~g}$; group III $=0.22 \pm 0.04 \mathrm{~g}$; group $\mathrm{IV}=2.62 \pm 0.33$ g; e group $\mathrm{V}=11.64 \pm 0.80 \mathrm{~g}$. The experiments were conducted independently for each group, using a completely randomized design, with six concentrations of eugenol (50, 75, 100, 125, 150 and $175 \mathrm{mg} \mathrm{L}^{-1}$ ) and 10 replicates (animals individually evaluated).

Fish were starved for $12 \mathrm{~h}$ before the experiment. Animals from each group were individually tested (as described before) with different concentrations of anesthetic in order to monitor the time sedation. Anesthesia was characterized by loss of reflexes to external stimuli and slow opercular movements as described by Small (2004). When the fish reached the dormant state, biometric data (weight and length) were obtained, followed by a recovery time when fish was placed in anesthetic-free water. The times required for the induction and recovery of fish were recorded individually and the latter also took into account the time spent for measuring length and weight. The biometric data was precisely timed in order to avoid the influence on the time of recovery from anesthesia. The fish were considered recovered from anesthesia when they showed certain set of signals, such as normal equilibrium reaction and external stimuli reaction, as described by Ross and Ross (2008). After the experiments, the fish from each replicate were pooled and kept in $30 \mathrm{~L}$ tanks in a recirculating water system in order to observe survival rate after $24 \mathrm{~h}$. At the end of the experiments, all fish were euthanized by anesthetic overdose. All procedures were carried out according to the international practices for animal use and care under the control of an internal Committee of the Universidade Federal de Minas Gerais, Brazil.

STATISTICAL ANALYSIS

The results were analyzed using SAS-Statistical Analysis System software (SAS 2002). The treatments were subjected to multiple regressions, using the method of least squares to estimate the regression coefficients, and Stepwise method to choose the regression equation that best describe the behavior in the stages of anesthesia and recovery of fish.

\section{RESULTS}

Water quality was monitored during the anesthetic procedures and the parameters, $\mathrm{pH}=7.83 \pm 0.38$, dissolved oxygen $=5.78 \pm 0.51$ and temperature $=$ $26.17 \pm 0.37$, were within the recommended ranges for freshwater fish (Vinatea 2004).

The eugenol concentration affected the induction time $(p<0.05)$ for each weight group of tilapia (Fig. 1). The concentration between 150 and $175 \mathrm{mg}$ $\mathrm{L}^{-1}$ can be used for group I ( $\left.0.02 \mathrm{~g}\right)$ and group V (11.64 $\mathrm{g}$ ), since these concentrations had the lowest sedation times (around 23 and 72 seconds, respectively).

Figure 2 demonstrates the relationship between exposure to eugenol concentrations and time of recovery of the different groups of tilapia.

After $24 \mathrm{~h}$ of testing, survival was $100 \%$ for the different groups of tilapia. Moreover, all the fish resumed eating.

\section{DISCUSSION}

In the present study, increasing concentrations of eugenol provided a time reduction of anesthesia in early life stages of tilapia. It was observed that the concentrations between 150 and $175 \mathrm{mg} \mathrm{L}^{-1}$ were 


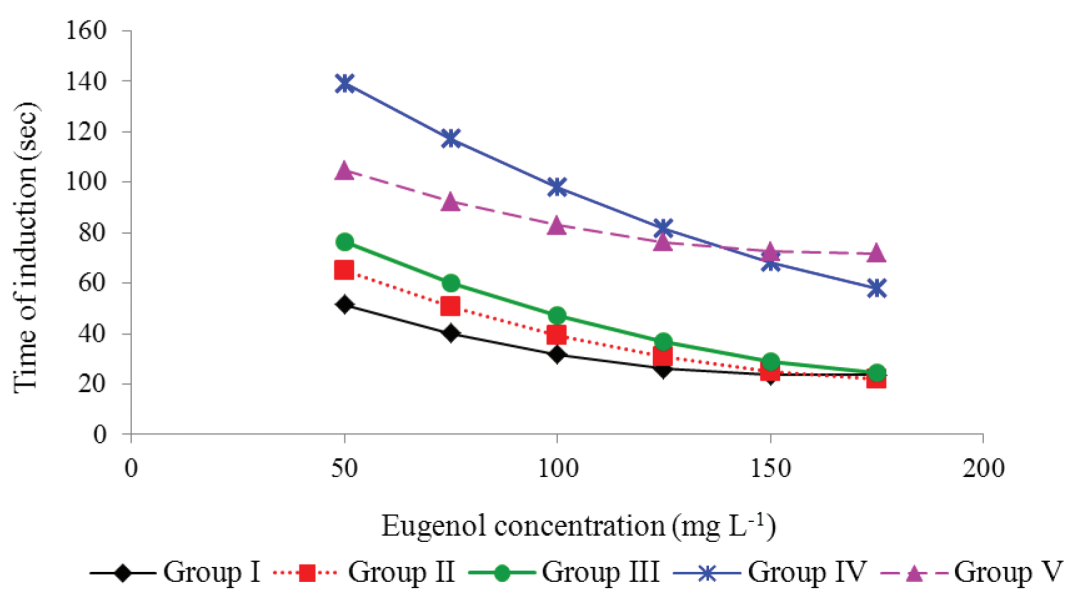

Figure 1 - Induction time to increasing concentrations of eugenol in different weight 1 groups of tilapia.

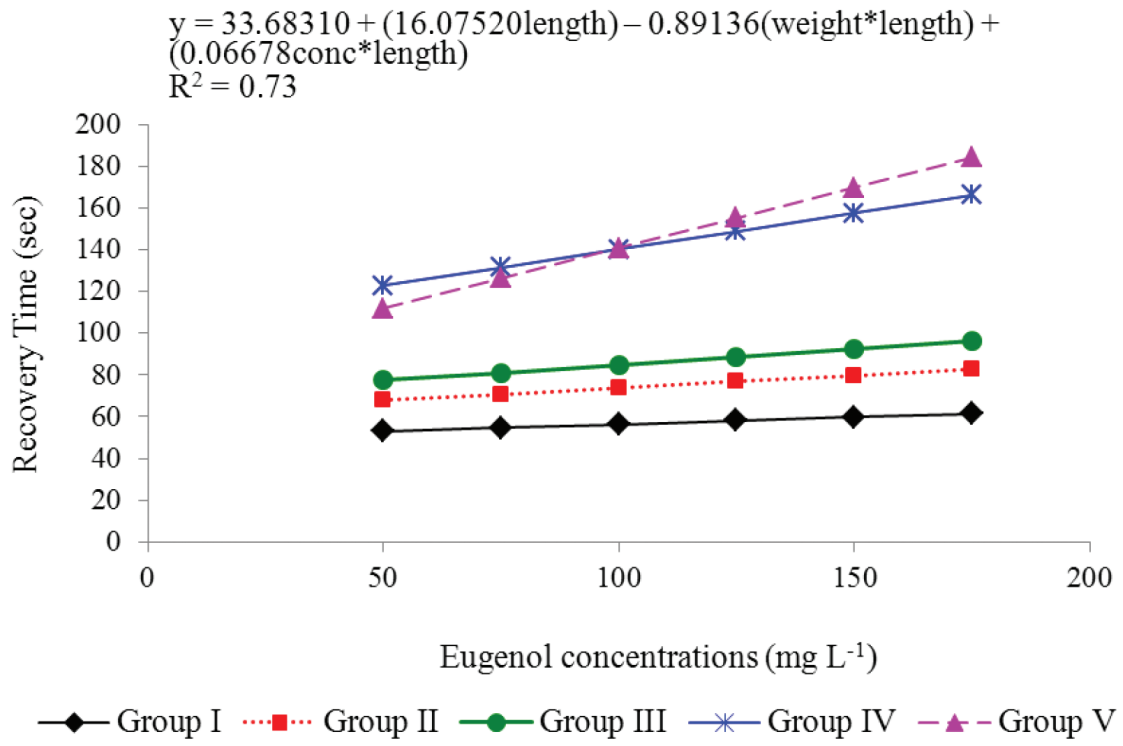

Figure 2 - Recovery time of groups of tilapia exposed to different concentrations of 1 eugenol.

efficient to anesthesize fish. The registered time did not exceed 180 seconds, time recommended by Keene et al. (1998) as ideal for induction time to the anesthesia condition.

Data regarding anesthesia with eugenol in the early life stages of fish are scarce. Pereirada-Silva et al. (2009) studied the effectiveness of eugenol on fingerlings (mean weight $=0.6 \mathrm{~g}$ ) of "lambari" Astyanax altiparanae and found that concentrations between 50 and $150 \mathrm{mg} \mathrm{L}^{-1}$ promotes deep anesthesia, in less than 90 seconds, however, mortalities following higher dosages (150 $\left.\mathrm{mg} \mathrm{L}^{-1}\right)$ were documented.

Eugenol was also effective in inducing deep anesthesia in juveniles (mean weight $=3.31 \mathrm{~g}$ ) of "matrinxã" Brycon cephalus. The concentrations of 50 to $100 \mathrm{mg} \mathrm{L}^{-1}$ of eugenol were effective in inducing and regarding recovery time (Vidal et 
al. 2007b). It has been described that larvae of sturgeon Acipenser gueldenstaedtii (mean length $=13.7 \mathrm{~mm}$ ) were anesthetized with $0.20 \mathrm{mg} \mathrm{L}^{-1}$ of eugenol (Akbulut et al. 2011) and juveniles of Pseudoplatystoma corruscans (mean weight $=27$ g) were anesthetized with $50 \mathrm{mg} \mathrm{L}^{-1}$ of eugenol (Vidal et al. 2006).

According to Vidal et al. (2008), a concentration of $75 \mathrm{mg} \mathrm{L}^{-1}$ of eugenol presented the best response of anesthesia for juvenile tilapia (mean weight $=5.34 \mathrm{~g}$ ); while $100 \mathrm{mg} \mathrm{L}^{-1}$ of eugenol was indicated for induction and recovery in older tilapias, with mean weight of $670 \mathrm{~g}$ (Simões et al. 2010) and also indicated for tilapia with mean weight of $47.73 \mathrm{~g}$, as described by Delbon and Ranzani-Paiva (2012).

According to Zahl et al. (2009, 2011), body weight is an important factor that affects the efficacy of the anesthetic agents, regarding induction and recovery times. In the current investigation, the response of larvae (time of induction) was shorter than in juveniles and this has been reported by Brown et al. (1972) as a result of the normal uptake of anesthetic across the skin being higher than through the gills. Opiyo et al. (2013) working with $O$. niloticus reported that body weight had a direct relationship with anesthetic concentration (sodium bicarbonate). Notwithstanding, Ribeiro et al. (2013) working with eugenol in two juvenile classes of Lophiosilurus alexandri (mean weight $=0.72$ and $7.44 \mathrm{~g}$, respectively), recommended the same concentration of this anesthetic $(120 \mathrm{mg}$ $\mathrm{L}^{-1}$ ) to both juvenile classes. Corroborating Ribeiro et al. (2013), Nile tilapia larvae and juveniles can be anesthetized with the same range of eugenol concentration (present manuscript).

According to Keene et al. (1998), the recommended time of animal recovery after anesthesia should remain below the limit of 300 seconds. In general, the augment of eugenol concentrations reflects increasing recovery time for the fish. Notwithstanding, for all tested concentrations of eugenol, the recovery time for the different groups of tilapia remained below (53.07 to 184.31 seconds) the recommended limit. Okamoto et al. (2009) working with dosages of eugenol between 25 and $75 \mathrm{mg} \mathrm{L}^{-1}$ observed a recovery time after induction varying from 120 to 480 seconds for juveniles (mean weight $=51.4 \mathrm{~g}$ ) of pompano Trachinotus marginatus. Concentrations of eugenol of 50 to $200 \mathrm{mg} \mathrm{L}^{-1}$ were used for induction of "matrinxã" juveniles. The recovery time after eugenol anesthesia ranged from 186 to 292 seconds.

According to the data presented it is possible to observe a wide range of eugenol concentrations to anesthetize the fish. It is noteworthy that eugenol has a large margin of safety, is easy to apply, and results in low stress for the fish and low risk to the animal (while out of water) and to the handler.

Comparing our results with published data, we conclude that the optimal concentrations to anesthetize the larvae of $O$. niloticus are similar to those observed for other species in early stages of development, and equal or higher in comparison to juveniles of Nile tilapia.

In addition, the survival rates showed that eugenol concentrations between 150 and $175 \mathrm{mg}$ $\mathrm{L}^{-1}$ may be considered safe for Nile tilapia larvae and juveniles, since they determine the shortest sedation time, 23 and 72 seconds, respectively. These results demonstrated the possibility of handling the animals avoiding death rates.

\section{ACKNOWLEDGMENTS}

The present research was supported by Fundação de Amparo à Pesquisa do Estado de Minas Gerais (FAPEMIG), Conselho Nacional de Desenvolvimento Científico e Tecnológico (CNPq) and Ministério de Pesca e Aquicultura (MPA).

\section{RESUMO}

$\mathrm{Na}$ aquicultura, as atividades com anestésicos são normalmente empregadas a fim de assegurar o bemestar dos peixes cultivados, permitindo a manipulação 
fora da água diminuindo desta forma o trauma por estresse. Atualmente, não há nenhuma informação sobre a ação anestésica do eugenol em fases iniciais de vida de tilápia do Nilo (Oreochromis niloticus). O objetivo deste estudo foi avaliar diferentes concentrações de eugenol para larvas e juvenis de tilápia do Nilo. Sessenta animais foram usados em cada grupo de peso, o grupo $\mathrm{I}=0,02 \mathrm{~g}$; grupo II $=$ $0,08 \mathrm{~g}$; grupo III $=0,22 \mathrm{~g}$; grupo $\mathrm{IV}=2,62 \mathrm{~g}$; e grupo $\mathrm{V}=11,64 \mathrm{~g}$. As concentrações de eugenol testadas foram $50,75,100,125,150$ e $175 \mathrm{mg} \mathrm{L}^{-1}$. Não houve mortes durante os testes com eugenol. Larvas de tilápia com $0,02 \mathrm{~g}$ e juvenis em torno de $11,64 \mathrm{~g}$ podem ser anestesiados com concentrações de eugenol entre 150 e $175 \mathrm{mg} \mathrm{L}^{-1}$, uma vez que determinam o menor tempo de sedação ( 23 e 72 segundos, para o grupo de peso menor e maior, respectivamente).

Palavras-chave: anestesia, ciclídeo, manipulação, bem-estar.

\section{REFERENCES}

ACerete L, BAlasch JC, Espinosa E, Josa A AND Tort L. 2004. Physiological responses in Eurasian perch (Perca fluviatilis, L.) subjected to stress by transport and handling. Aquaculture 237: 167-178.

AKbulut B, ÇAVDAR Y, ÇAKMAK E AND AKsungur N. 2011. Use of clove oil to anaesthetize larvae of Russian sturgeon (Acipenser gueldenstaedtii). J Appl Ichthyol 27: 618-621.

ANDERSON WG, MCKinLEY RS AND COLAVECCHIA M. 1997. The use of clove oil as an anesthetic for rainbow trout and its effects on swimming performance. North Am J Fish Manage 17: 301-307.

BRESSLER K AND RON B. 2004. Effect of anesthetics on stress and the innate immune system of gilthead bream (Sparus aurata). Isr J Aquacult 56: 5-13.

Brown EAB, Franklin JE, Pratt E and Trams EG. 1972. Contributions to the pharmacology of quinaldine uptake and distribution in the shark and comparative studies. Comp Biochem Physiol 42A: 223-231.

Charoendat $\mathrm{U}$, AREechon $\mathrm{N}$, SRISAPOOME $\mathrm{P}$ AND CHANTASART D. 2009. The efficacy of synthetic eugenol as an anesthetic for tilapia (Oreochromis niloticus Linn.) fry. Kasetsart J (Nat Sci) 43: 132-140.

CHO GK AND HEATH DD. 2000. Comparison of tricaine methanesulphonate (MS 222) and clove oil anaesthesia effects on the physiology of juvenile Chinook salmon Oncorhynchus tshawytscha (Walbaum). Aquacult Res 31: 537-546.
DA CUNHA MA, ZEPPENFEld CC, GARCIA LO, LORO VL, DA Fonseca MB, EMANUElli T, VEeck APL, COPATtI CE AND BALDISSEROTTO B. 2010. Anesthesia of silver catfish with eugenol: time of induction, cortisol response and sensory analysis of fillet. Cienc Rural 40(10): 2107-2114.

DELbon MC AND RANZANI-PAIVA MJT. 2012. Eugenol em juvenis de tilápias no Nilo: concentrações e administrações sucessivas. Bol Inst Pesca 38(1): 43-52.

FDA - Food AND DRUG AdMinistration. 2002. Status of clove oil and eugenol for anesthesia in fish. Guidance for industry. U.S. Department of Health and Human Services, Rockville, MD, 4 p.

Gomes DP, Chaves BWC, BeCKer AG AND BALDISSERotTo B. 2011. Water parameters affect anaesthesia induced by eugenol in silver catfish, Rhamdia quelen. Aquacult Res 42: $878-886$

GRIFFITHS SP. 2000. The use of clove oil as an anesthetic and method for sampling intertidal rockpool fishes. J Fish Biol 57: 1453-1464.

GuÉnette SA, Uhland FC, Hélie P, BeAudRY F AND VACHON P. 2007. Pharmacokinetics of eugenol in rainbow trout (Oncorhynchus mykiss). Aquaculture 266: 262-265.

HONCZARYK A AND INOUE LAKA. 2009. Anestesia do pirarucu por aspersão direta nas brânquias do eugenol em solução aquosa. Cienc Rural 39(2): 577-579.

Hoskonen P AND PIRHONEN J. 2004. Temperature effects on anesthesia with clove oil in six temperate-zone fishes. J Fish Biol 64: 1136-1142.

HovDA J AND LINLEY TJ. 2000. The potential application of hypothermia for anesthesia in adult pacific salmon. North Am J Aquacult 62: 67-72.

INOUE LAKA, SANTOS NETO CAND MORAES G. 2003. Clove oil as anaesthetic for juveniles of matrinxã Brycon cephalus (Gunther, 1869). Cienc Rural 33(5): 943-947.

KeEne JI, NoAKes DIG, Moccia RD AND Soto GC. 1998. The efficacy of clove oil as an anesthetic for rainbow trout, Oncorhynchus mykiss (Walbaum). Aquacult Res 29: 89-101.

MARKING LL AND MEYER FP. 1985. Are better fish anesthetics needed in fisheries? Fisheries, Bethesda 10(6): 2-5.

OKamoto MH, Tesser MB, LOUZada LR, Dos SANTOS RA AND SAMPAIO LA. 2009. Benzocaína e eugenol como anestésicos para juvenis do pampo Trachinotus marginatus. Cienc Rural 39(3): 866-870.

OPIYO MA, OGELLO EC AND CHARO-KARISA H. 2013. Effectiveness of sodium bicarbonate as an anesthetic for different sizes of Nile tilapia (Oreochromis niloticus L., 1758) juveniles. Int J Aquat Sci 4(2): 14-22.

Palic D, Herolt DM, Andreasen CB, Menzel BW AND Roth JA. 2006. Anesthetic efficacy of tricaine methanesulfonate, metomidate and eugenol: effects on plasma cortisol concentration and neutrophil function in fathead minnows (Pimephales promelas Rafinesque, 1820). Aquaculture 254: 675-685.

PEREIRA-DA-Silva EM, DE OliveIRA RHF, RibeIRo MAR AND Coppola MP. 2009. Efeito anestésico do óleo de cravo em alevinos de lambari. Cienc Rural 39(6): 1851-1856. 
Ribeiro PAP, Miranda-Filho KC, MElillo-Filho R, SANTOS AEH, SILVA WSS, RODRIGUES LA AND LUZ RK. 2013. Eugenol como anestésico para juvenis de pacamã. Pesq Agropec Bras 48(8): 1136-1139.

Ross LG AND Ross B. 2008. Anaesthetic and sedative techniques for aquatic animals. $3^{\text {rd }}$ ed., Oxford: Blackwell Science, $236 \mathrm{p}$.

RoubACH R, GOMES LC, FONSECA FAL AND VAL AL. 2005. Eugenol as an efficacious anaesthetic for tambaqui, Colossoma macropomum (Cuvier). Aquacult Res 36(11): 1056-1061.

SAS - Statistical AnAlysis System. 2002. User's guide. Version 9.1. Cary: SAS Institute Inc., CD-ROM.

Simões LN, PAIVA G AND Gomes LC. 2010. Óleo de cravo como anestésico em adultos de tilápia-do-Nilo. Pesq Agropec Bras 45: 1472-1477.

SMALL BC. 2004. Effect of isoeugenol sedation on plasma cortisol, glucose, and lactate dynamics in channel catfish Ictalurus punctatus exposed to three stressors. Aquaculture 238: 469-481.

Vidal LVO, Albinati RCB, Albinati ACL, De LiRa AD, De Almeida TR AND SANTos GB. 2008. Eugenol como anestésico para a tilápia-do-Nilo. Pesq Agropec Bras 43: 1069-1074.
Vidal LVO, Albinati RCB, Albinati ACL And De MaCedo GR. 2006. Utilização do Eugenol como Anestésico para o Manejo de Juvenis de Pintado (Pseudoplatystoma corruscans). Acta Sci Biol Sci 28(3): 275-279.

VidAl LVO, FuruYa WM, GRACIANO TS, SCHAMBER CR, SILVA LCR, SANTOS LD AND SouZA SR. 2007b. Eugenol como anestésico para juvenis de matrinxã (Brycon cephalus). Rev Bras Saude Prod Anim 8: 335-342.

Vinatea L. 2004. Princípios químicos de qualidade de água em aquacultura: uma revisão para peixes e camarões. $2^{\mathrm{a}}$ ed., Florianópolis: Ed. UFSC, 231 p.

WALSh CT AND PEASE BC. 2002. The use of clove oil as an anesthetic for the long finned eel, Anguilla reinhardtii (Steindachner). Aquacult Res 33: 627-635.

WATERSTRAT PR AND PINKHAM L. 2005. Evaluation of eugenol as an anesthetic for the American lobster Homarus americanus. J World Aquacult Soc 36(3): 420-424.

WoOdy CA, Nelson J AND RAMSTAD K. 2002. Clove oil as an anesthetic for adult sockeye salmon: field trails. J Fish Biol 60: 340-347.

Zahl IH, Kiessling A, SAmUelsen OB and Hansen MK. 2009. Anaesthesia of Atlantic cod (Gadus morhua) effect of pre-anaesthetic sedation, and importance of body weight, temperature and stress. Aquaculture 295: 52-59. 
